Guido Bartolucci

\title{
Jewish Scepticism in Christian Eyes: Jacob F. Reimmann and the Transformation of Jewish Philosophy
}

\section{Introduction}

Christian interest in the Jewish tradition in the modern age has long been recognised as an important field of research for understanding the history of European erudition, along with the study of Greek and Latin. Less investigated, however, is the relationship between this interest and the construction of definitions of Jewish tradition, culture and history that, built within the Christian field, ended up also becoming heritage of the field that had been the subject of these investigations, namely Judaism iseitself. ${ }^{1}$ A particular case concerns the definition of 'Jewish philosophy.' This concept, in fact, has engaged scholars at least in the last century in attempts to reconstruct its history and to find a definition that would at last capture its 'essence', in a continuous oscillation between two extreme poles: the rejection of the existence of a Jewish philosophy at all and instead its centrality in understanding the history of Judaism itself. ${ }^{2}$ Thus, in the introduction to an important volume on Jewish philosophy, the editor Daniel Frank writes:

\footnotetext{
This article is just a preliminary result of a research on Jewish scepticism and Jewish philosophy in the Lutheran world of the Early modern period undertaken during my fellowship at the Maimonides Centre for Advanced Studies, Universität Hamburg.
}

1 On Christian Hebraism and the history of erudition, see François Secret, Les kabbalistes chrétiens de la Renaissance (Paris: Dunod, 1964); Jerome Friedman, The Most Ancient testimony: Sixteenth-Century Christian-Hebraica in the Age of Renaissance Nostalgia (Athens: Ohio University Press, 1983); Frank E. Manuel, The Broken Staff: Judaism through Christian Eyes (Cambridge, MA: Harvard University Press, 1992); Saverio Campanini, "Die Geburt der Judaistik aus dem Geist der Chrislichen Kabbalah," in Gottes Sprache in der philologischen Werkstatt: Hebraistik vom 15. bis zum 19. Jahrhundert, ed. Giuseppe Veltri and Gerold Necker (Leiden: Brill, 2004): 135-241; Anthony Grafton and Joanna Weinberg, "I have always loved the Holy Tongue": Isaac Casaubon, the Jews, and a forgotten chapter in Renaissance scholarship (Cambridge, MA: The Belknap Press of Harvard University Press, 2011); Theodor Dunkelgrün, "The Christian Study of Judaism in Early Modern Europe," in The Cambridge History of Judaism, vol. 7: The Early Modern World, 1500-1815 (Cambridge: Cambridge University Press, 2017): 316-348. For a comprehensive bibliography, see Stephen G. Burnett, Christian Hebraism in the Reformation Era (1500-1660): Authors, Books, and the Transmission of Jewish Learning (Leiden: Brill, 2012).

2 On this debate, see, e. g., in the present volume Dirk Westerkamp, "Quaestio sceptica disputata de philosophia judaeorum: Is there a Jewish Philosophy?," in Yearbook of the Maimonides Centre for Advanced Studies 2018, ed. Bill Rebiger (Berlin and Boston: De Gruyter, 2018): 3-14. 
Much the most important part of any answer we give to our initial query into the nature of Jewish philosophy is that Jewish philosophy is an academic discipline. It is an invention, for reasons important to ponder, of nineteenth-century historians, intent on bringing together certain thinkers, while simultaneously excluding others. Before the invention of Jewish philosophy as an academic discipline no one asked or wondered about the nature of Jewish philosophy, quite simply because the subject did not exist. [...] No one in premodern, indeed, in much of modern times understood Jewish philosophy as a subdiscipline of philosophy, as a way of philosophizing. No one felt the need to ascertain the essence of Jewish philosophy [...] distinguishing it from every other kind of philosophy or mode of theological interpretation. ${ }^{3}$

All these assertions could probably be applied to the Jewish world, starting at the beginning of the Wissenschaft des Judentums. ${ }^{4}$ The Christian tradition, however, did not wait for the nineteenth century in order to reflect on Jewish philosophy. Its interest had begun far earlier, at the very least by the fifteenth century. ${ }^{5}$ The question of Jewish philosophy in the history of Christian thought developed in a completely different way than what took place in the Jewish milieu. Jewish authors, such as Simone Luzzatto and Moses Mendelssohn, for example, envisaged their own philosophical thinking as something autonomous from religious tradition, whereas Christian authors attempted quite the opposite. Many Christian scholars were interested in Jewish philosophy for its alleged holiness, as we will see forthwith. But the history of this encounter is particularly significant in understand the interpretation of the meaning of Jewish Scepticism, because it was the Christian milieu (not the Jewish one) that first maintained the Jewish thought could be regarded as a sceptic philosophy. ${ }^{6}$

3 Daniel H. Frank, "What is Jewish philosophy," in History of Jewish Philosophy, eds. Daniel H. Frank and Oliver Leaman (London and New York: Routledge, 1997): $2-4$.

4 On Jewish philosophy, see The Cambridge History of Jewish Philosophy: From Antiquity through the Seventeenth Century, eds. Steven H. Nadler and Tamar M. Rudavsky (Cambridge: Cambridge University Press, 2009); The Cambridge Companion to Medieval Jewish Philosophy, eds. Daniel H. Frank and Oliver Leaman (Cambridge: Cambridge University Press, 2003); The Cambridge Companion to Modern Jewish Philosophy, eds. Michael L. Morgan and Peter Eli Gordon (Cambridge: Cambridge University Press, 2007); Giuseppe Veltri, Sapienza Alienata (Rome: Aracne, 2015); Josef Stern, "What is Jewish Philosophy? A View from the Middle Ages," in Yearbook of the Maimonides Centre for Advanced Studies 2017, ed. Bill Rebiger (Berlin and Boston: De Gruyter, 2017): 185-204; Giuseppe Veltri, Alienated Wisdom. Enquiry into Jewish Philosophy and Scepticism (Berlin and Boston: De Gruyter, 2018).

5 On Jewish philosophy in Christian debate, see Dirk Westerkamp, Die philonische Unterscheidung. Aufklärung, Orientalismus und Konstruktion der Philosophie (München: Wilhelm Frank, 2009); idem, "The Philonic Distinction: German Enlightement Historiography of Jewish Thought," History and Theory 47 (2008): 533 - 559; Haim Mahlev, "A Philosophy of the Patriarchs? The Agenda Behind Christoph August Heumann's Acta Philosophorum,” Journal of the History of Ideas 76.4 (2015): 517-539. 6 On Jewish scepticism, see Giuseppe Veltri, "Principles of Jewish Skeptical Thought. The Case of Judah Moscato and Simone Luzzatto," in Rabbi Judah Moscato and the Jewish Intellectual World of Mantua in 16th-17th Centuries, eds. Giuseppe Veltri and Gianfranco Miletto (Boston and Leiden: Brill, 2012): 15-36; idem, "Maharal against Azaria de Rossi: The Other Side of Skepticism," in Rabbinic Theology and Jewish Intellectual History: The Great Rabbi Loew of Prague, ed. Meir Seidel (Ox- 
Jacob Friedrich Reimmann (1668-1743), a Lutheran scholar, published a short essay in 1704 arguing under the provocative title "An Salomon fuerit scepticus?" ("Was Solomon a Sceptic?") that the essence of Jewish philosophy is scepticism. ${ }^{7}$ To understand this fundamental passage, so decisive for the history of the reception of Jewish thought in the Christian culture of the early modern age, it is, however, necessary to carry out two preliminary steps: the first is to reconstruct the history of Christian interest in Jewish philosophy, the second is to understand the role played by the Lutheran world in this history.

\section{Christian Discovery of Jewish Tradition}

In the fifteenth century a phenomenon emerged in European culture-later to be defined as Christian Hebraism - this was the attempt to apply philological techniques, developed from the study of Latin and Greek texts, to the Hebrew text of the Bible and from there proceed to other sources of the Jewish tradition. This new approach profoundly changed the way of thinking about Judaism, widening the boundaries within which it had previously been understood. The new sources, studied in the original language, as far as this was possible at the time, not only helped to rethink the Christian tradition, but also gave access to previously unknown new texts and traditions. The use of philological instruments similar to those impemented for Greek and Latin sources also brought with it the need to use interpretative categories capable of bringing the Jewish tradition to the level of other Classical traditions. Until that time, the Hebrew tradition was not regarded comparable to the Greek and Latin cultures. ${ }^{8}$ During this period a new instrument was introduced to interpret the Jewish tradition and legitimise its use. At the beginning of the fifteenth century, several authors borrowed a scheme from the works of the Greek Church Fathers, that divided the history of the Jews into two periods: the ancient, pure and primeval Hebraism of the patriarchs, and a modern Judaism corrupted by a literal interpretation of Mosaic law. This two-stage scheme was especially important in the second half of fifteenth century, for the development of a new idea of Hebraica veritas. ${ }^{9}$ Several au-

ford: Oxford University Press, 2012): 65-76; idem, "Do/Did the Jews Believe in God? The Skeptical Ambivalence of Jewish Philosophy of Religion," in Envisioning Judaism: Studies in Honor of Peter Schäfer on the Occasion of his Seventieth Birthday, vol. 2, eds. Ra'anan Boustan et alii (Tübingen: Mohr Siebeck, 2013): 717-733; see also Veltri, Alienated Wisdom.

7 See note 32.

8 Cf. Jonathan Friedman, "The Myth of Jewish Antiquity: New Christians and Christian-Hebraica in Early Modern Europe," in Jewish Christians and Christian Jews: From Renaissance to the Enlightenment, eds. Richard H. Popkin and Gordon M. Weiner (Dordrecht, Boston and London: Kluwer Academic Publishers, 1994): 35-55.

9 Cf. Riccardo Fubini, Storiografia dell'Umanesimo in Italia. Da Leonardo Bruni ad Annio da Viterbo (Rome: Edizioni di Storia e Letteratura, 2003), 290 - 333; Jean Sirinelli, “Introduction générale,” in Eu- 
thors, such as Marsilio Ficino and Pico della Mirandola, justified their own interest in the Jewish tradition by maintaining that, for example, the Kabbalah was part of original Jewish wisdom, and not linked to modern Judaism. ${ }^{10}$ This new attitude toward Judaism, which will not be analysed in depth here, contributed to the 'Judaisation' of European culture itself. ${ }^{11}$ In using the term Judaisation I intend to refer to a process of increasing incorporation of Jewish works and authors into the myth of a single original ancient wisdom, where the Bible and Jewish literature (i.e. the part of it considered to be more ancient) came to be seen as sources that maintained their validity for all mankind.

This introduction was necessary to understand how the birth of interest in Jewish philosophy of the second half of the sixteenth century links to a Christian Hebraism that, in some aspects, was influenced by the prisca theologia, applying its approach to various fields of interest, within the framework of a genealogical construction of human knowledge rooted in ancient Jewish wisdom. ${ }^{12}$ There are, however, different traditions that take the name prisca theologia: 1) one which saw in the Jewish tradition the only true pre-Christian revelation which reached the gentiles through the Egyptians who were instructed by Moses 2) a series of other pre-Christian revelations different and independent from the Jewish one. While the first was considered more orthodox, being approved by the fathers of the Church and maintaining a link with the Old Testament, the second was considered more dangerous as it implied that

sebius of Caesarea, La préparation évangélique, vol. 1, eds. Jean Sirinelli and Edouard des Places (Paris: Cerf, 1974), 7-62.

10 See Guido Bartolucci, Vera religio. Marsilio Ficino e la tradizione ebraica (Turin: Paideia, 2017); Flavius Mithridates, Sermo de passione Domini, ed. Chaim Wirszubski (Jerusalem: Academy of Science, 1963).

11 On this idea, see, e.g., Robert Dan, “Judaizare’: the Career of a Term,” in Antitrinitarianism in the Second Half of the 16th Century, eds. Robert Dan and Antal Pirnat (Budapest and Leiden: Akademiai Kiado and Brill, 1982): 25-34.

12 See, e.g., Cesare Vasoli, “Il mito dei 'prisci theologi' come 'ideologia' della 'renovatio'," in idem, Quasi sit Deus. Studi su Marsilio Ficino (Lecce: Conte, 1999): 11-50. On prisca theologia, cf. Maria Muccillo, Platonismo, Ermetismo e 'prisca theologia'. Ricerche di storiografia filosofica rinascimentale (Florence: Olschki, 1996); Francis A. Yates, Giordano Bruno and the Hermetic Tradition (London: Routledge, 1964); Daniel P. Walker, The Ancient Theology: Studies in Christian Platonism from the Fifteenth to the Eighteenth Century (Ithaca, NY: Cornell University Press, 1972); Eugenio Garin, Ermetismo del Rinascimento (Rome: Editori riuniti, 1988); Charles B. Schmitt, "Prisca theologia e philosophia perennis," in Il pensiero italiano del rinascimento e il nostro tempo, Atti del V convegno internazionale del centro di studi umanistici Montepulciano, Palazzo Tarugi, 8-13 agosto 1968, ed. Giovannangiola Tarugi (Florence: Olschki, 1970): 211-236; Martin Mulsow, “Ambiguities of the Prisca Sapientia in Late Renaissance Humanism,” Journal of the History of Ideas 65 (2004): 1-13; Wilhelm Schmidt-Biggemann, Philosophia Perennis: Historical Outlines of Western Sprirituality in Ancient, Medieval and Early Modern Thought (Dordrecht: Springer, 2004); Moshe Idel, "Prisca Theologia in Marsilio Ficino and in some Jewish Treatments," in Marsilio Ficino: his Theology, his Philosophy, his Legacy, eds. Michael Allen and Valery Rees (Leiden, Boston and Köln: Brill, 2002): 137-158. 
some pagan philosophers had acquired knowledge of the truth equal to that of revealed religions.

In the history of prisca theologia these distinctions have a circumscribed value, since the different traditions intertwine and overlap each other, often preventing a clear distinction between ortodoxy and heresy or merely marking the differences between the various Christian confessions. However, it is important to note that such traditions succeeded in considering Jewish thought readable and interpretable with the tools of classical tradition. Also, in one of his most important works, Marsilio Ficino, one of the initiators of the prisca theologia, the De Christiana religione, maintained both positions, quoting the chain of wisdom that he had inherited from Gemisto Plethon on the one hand and introducing Eusebius' vision of a Jewish origin of Greek philosophical tradition on the other. ${ }^{13}$

I will report below some passages that best exemplify what we want to maintain here. One of the best known examples of this tradition is the debate on the origin of languages Guillaume Postel (1510-1581), hebraist, philosopher and self-acclaimed prophet, presented in his work De originibus seu de Hebraismi antiquitate, linguarum affinitate. Here he advocated the antiquity of the Hebrew language, using this argument to reconstruct the chain of human wisdom from the Jews to the Greeks. ${ }^{14}$ The influence of this idea on sixteenth century culture is not limited to language but extends to other fields of knowledge, identifying, for instance, Moses as the inventor of poetry, an assumption that the first humanists, for reasons mentioned earlier, refused absolutely. The work of the French hebraist Gilbert Génébrard (1535-1597) is useful in understanding how the ideology of prisca theologia was able to take different forms. In fact, in his main work, the Chronographia, Génébrard refused the antiquity and the authority of Hermes Trismegistus, while, at the same time, used excerpts

13 Marsilio Ficino, Opera quae hactenus extitere et quae in lucem nunc primum prodiere omnia (Basel: Officina Henricpetrina, 1576), 25: 'Prisca gentilium theologia in qua Zoroaster Mercurius Orpheus Aglaophemus Pythagoras consenserunt tota in Platonis nostri voluminibus continetur;' ibidem, 30: 'Ex quibus apparet quod Clemens Alexandrinus et Atticus Platonicus et Eusebius et Aristobolus probant gentiles videlicet, siqua habuerunt egregia dogmata et misteria, a Iudeis usurpavisse. [...]. Plato usqueadeo Iudeos imitatus est, ut Numenius Pytagoricus dixerit Platonem nihil aliud fuisse quiquam Moysen actica lingua loquentem. Addit in libro de bono Pythagoram quoque iudaica dogmata sectatum fuisse. [...] Clearcus Peripateticus scribit Aristotelem fuisse Iudeum, Calanos quoque phylosophus apud Indos Iudeos fuisse. Megastenes insuper brachmanas Indiae phylosophos a Iudeis asserit descendisse. Ambrosius recte memini Pythagoram patre Iudeo natum ostendit.'

14 Guillaume Postel, De originibus seu de Hebraismi antiquitate, linguarum affinitate (Paris: Dyonisius Lescuier, 1538), Aiiiir-v: 'Primam [linguam] fuisse Chaldaeam seu Hebraeam constat et authoribus prophanis et sacris, ut ethnicis fiat fides Deo electis christianis amplificetur. Praeter illa antiquissima Graecorum de hac re testimonia, quae tam insignis author Iosephus, cui in civitate eloquentissima ob insignem peritiam, eruditionem, et in scrivendo candorem, statua donata est, quem veritatis odio supprimunt sui Iudei, in libris Antiquitatum Iudaicarum et contra Appionem Grammaticum adfert. Praeter etiam illa quae amplissima adducit Eusebius Caesariensis de Evangelico apparato, cognosces hic non levibus argumentis, hanc Hebraicam linguam sua vocabula insignoribus orbis terrarum provinciis olim per filios Noachi dedisse.' 
from the Fathers of the Church, Eusebiusin particular, to maintain the dependence of Greek wisdom on the Jews. He identifies Moses as the first poet and initiator of this discipline. ${ }^{15}$ Beyond the specific meaning of these statements, which certainly had polemical intent within the world of Humanae litterae in the second half of the sixteenth century, it is important to stress here the 'disciplinary' legitimation acquired by the Jewish tradition, to the point that in some milieus it challenges and sometimes exceeds the Greek and Latin traditions. Génébrard's short discussion of Jewish poetry is valid not only in itself, but it is also evidence of a peculiar interest in the Jewish tradition. Similarly, Henri Estienne (1528/31-1598), a Calvinist printer and editor of the first edition of the Orphic fragments, published an anonymous ancient tractate in 1580, the Collatio legum Mosaicarum et Romanarum, which developed a parallel between Mosaic laws and the laws of the twelve tables. Although the French lawyer François Pithou (1543-1621) had already published this work, Estienne wrote an introduction of particular salience to this discussion. ${ }^{16}$ As already emphasised in the title of his work, Estienne wanted to distinguish between sources and rivers of the law, trying to reach the first ones. He identified these sources as the laws given by God to Moses, which the Egyptians then imitated and subsequently imparted to the Greeks. ${ }^{17}$ The introduction of the Calvinist editor helps us see how the idea that Jewish laws were the source of Roman and Greek laws circulated in the European culture of the second half of the Sixteenth century, using precisely the patterns characteristic of the earlier prisca theologia.

In the same way, a century later, an identical scheme was used to build a genealogy that could legitimise scientific theories, which otherwise would have been hardly

15 Gilbert Génébrard, Cronographiae libri quatuor (Paris: Martinus Iuvenis, 1578), 78: 'Moses poëtis omnibus praeluxit. Nam Iobi historiam spondaicis versibus repraesentavit et Cantica seorsum illud Deut. 32 elegiaco carmine, ut versus alternatim senis et quinis constent pedibus. (Eus. Lib. 11 Praep. Cap. 3; Hieron. Ex Iosepho). Ad quos modos tria extant cantica apud Esaiam, vincae scilicet, urbis Sion et Ezechiae. (Isidor.) Quod aemulati Graeci veteres, hexametris suas cantiones et odas conficiebant.'

16 Pierre Pithou, "Collatio legum Mosaicarum et Romanarum," in Observationes ad Codicem et Novellas Iustiniani Imperatoris, eds. Pierre and François Pithou (Paris, 1689): 33. Petrus Pithou, a French jurist and a disciple of the jurist Jacques Cujas, published an edition of this anonymous work written around the fourth century which systematically compares the laws found in the Old Testament with those described by some ancient jurists in order to find common points between them. On the tradition of the Mosaic law, see Guido Bartolucci, La repubblica ebraica di Carlo Sigonio (Florence: Olschki, 2007), 177-184.

17 Henri Estienne, Iuris civilis fonte set rivi, Iurisconsultorum veterum quidam loci, ex integris eorum voluminibus ante Iustiniani aetatem excerpti (Basel, 1580), 1r: 'Atque hoc appello nomine rivos eos qui ex primariis potius rivis quam ex ipsis fontibus manasse videri queunt. Ita enim mea fert opinio, sicut primos legislatores Aegyptios ex Mosaica Politia pleraque (praesertimque ea quae legi naturae consentanea videbantur) ita Graecos ex Aegiptiis multa sumpsisse. [...] Quod si mihi de quapiam meorum etiam maiorum lege mentionem licet facere, nullam post Mosaicam (quae Deum ipsum autorem habuit not homines) inveniemus, quae peregrinos aeque commendatos habeat ac Celtica.' 
sustainable. One of these attempts formulated the coincidence between the Epicurean theory of atoms and the Book of Genesis:

\begin{abstract}
We have also good historical probability for this Opinion, that this Philosophy was a thing of much greater Antiquity than either Democritus or Leucippus; and first, because Posidonius, an ancient and learned philosopher, did (as both Empiricus and Strabo tell us) avouch it for an old tradition, that the first Inventour of this Atomical Philosophy was one Moschus, a Phoenician, who, as Strabo also notes, lived before the Trojan War. [...] and Mr. Selden approves of the conjecture of Arcerius, the publisher of Iamblicus, that this Monchus was no other than the celebrated Moses of the Jews, with whose successors, the Jewish philosophers, priests, and prophets, Pythagoras conversed at Sidon. ${ }^{18}$
\end{abstract}

In this passage Ralph Cudworth (1617-1688), one of the most important Cambridge Platonists, uses themes and authors characteristic of the prisca theologia, clearly showing that, in mid-seventeenth century, this ideology still had a political and cultural implication. To infuse the atomistic theory with a mosaic aurea (without any philological and historical basis) gave him the opportunity to legitimise theories that were distant to any recognised orthodoxy.

These three cases are merely an example of the tranformation of the Christian perception of Jewish tradition. The framework developed by the humanists of the prisca theologia gave the European scholars an opportunity to think Judaism out of the traditional theological path. They now had the tools to interpret Jewish history as part of the history of language, poetry or law. Thus, this use of the sources of prisca theologia and of the interpretation of the Fathers of the Church and also gave them the chance to insert Judaism within the history of philosophy.

\title{
2 The Jewish Tradition in Germany in the Seventeenth Century and the History of Philosophy
}

At the same period in Germany, within the Lutheran world, we witness the diffusion of works whose main topic was the philosophical and political tradition of the Jews. Some of these treatises, published at the end of the seventeenth century, aimed to demonstrate not only that a Jewish philosophy existed, but also that it had influenced the Western philosophical tradition. The formulas and the sources used by these authors demonstrate their familiarity with the idea just outlined. On the other hand, other works, maintained the complete irrelevance of the Jewish tradition

18 Danton B. Sailor, "Moses and Atomism," Journal of the History of Ideas 25.1 (1964): 11. Cf. Ralph Cudworth, The True Intellectual System of the Universe, wherein all the Reason and Philosophy of Atheism is Confuted, and its Impossibility Demonstrated (London: Richard Royston, 1678), 12-13. On philosophia perennis and the history of philosophy in England in this period, see Dmitri Levitin, Ancient Wisdom in the Age of the New Science: Histories of Philosophy in England, c. 1640-1700 (Cambridge: Cambridge University Press, 2015). 
for the development of Greek and European philosophy, for its closeness to theology. ${ }^{19}$

The question of Jewish philosophy and its connection to the other philosophical traditions also became important for the first historians of philosophy who published their works in the second half of the seventeenth century. The Protestant world in particular was interested in the history of pagan philosophy: these authors were not attempting to trace an erudite history of human knowledge, but sought to implement this history in a polemical manner. From the second half of the seventeenth century, the Lutheran universities of the German States began to produce an ever-increasing number of small and large treatises concerned with both the history of philosophy and the history of theology. ${ }^{20}$ From its foundation on, the Reformation had recognised the common path of these two disciplines, by composing either philosophical histories of theology (i.e. Christianity) or theological histories of philosophy (both Greek and 'Barbaric'). ${ }^{21}$

At the outset (i.e. from the sixteenth century), Greek philosophy was recognised as one of the sources of the corruption of original Christianity. Soon, however, the confrontation with other confessions (Calvinism and Catholicism), forced Lutheranism to embrace philosophy and Aristotelian thought ${ }^{22}$ in particular. The relationship between philosophy and theology was subjected to increasingly insistent and targeted attacks during the seventeenth century, when new methods of philosophy

19 Cf. Valerio Marchetti, "Sulla degiudaizzazione della politica. In margine alla relazione di Horst Dreitzel," in Aristotelismo politico e ragion di stato, Atti del convegno internazionale di Torino 11-12 Febbraio 1993, ed. Artemio Enzo Baldini (Florence: Olschki, 1995): 349-358; idem, "An Pythagoras proselytus factus sit," Dimensioni e problemi della ricerca storica 2 (1996): 111-121; idem, "Aristoteles utrum fuerit Iudaeus. Sulla degiudaizzazione della filosofia europea in età moderna," in Anima e paura. Studi in onore di Michele Ranchetti, ed. Anna Scattigno (Macerata: Quodlibet, 1998): 249-266; Giuseppe Veltri, “Academic Debates on the Jews in Wittenberg. The Protestant Literature on Rituals, the Dissertationes and the Writings of the Hebraists Theodor Dassow and Andreas Sennert," European Journal of Jewish Studies 6 (2012): 123 - 146; Guido Bartolucci, "Jewish Thought vs. Lutheran Aristotelism: Johann Frischmuth (1619-1687) and Jewish Scepticism," in Yearbook of the Maimonides Centre for Advanced Studies 2017, ed. Bill Rebiger (Berlin and Boston: De Gruyter, 2017): 95-106.

20 Cf., e.g., Jacob Thomasius, Origines Historiae philosophicae et Ecclesiasticae (Halle and Magdeburg: Johann Gottfred Renger, 1699).

21 For these pages I refer to Luciano Malusa, "Renaissance Antecedents to the Historiography of Philosophy," in Models of the History of Philosophy, vol. 1: From Its Origins in the Renaissance to the 'Historia Philosophica', eds. Giovanni Santiello et alii (Dordrecht: Kluwer Academic Publishers, 1993): 53-58; Giovanni Santiello, "The 'Historia Philosophica' in German Scholastic Thought," in ibidem, $373-442$.

22 Cf., e.g., Delio Cantimori, "Umanesimo e luteranesimo di fronte alla scolastica: Caspar Peucer," Rivista di studi germanici 2 (1937): 417-438. 
emerged, inside and outside the Reformation, creating new conceptions of the history of Lutheranism and new theological challenges. ${ }^{23}$

The history of philosophy, thus, acquired an important role in polemical debate within the Lutheran World. Studying the history of the different schools of philosophers involved reflecting on the different philosophical methods useful in understanding not only the history of thought, but also the history of the Church, and the history of the relationship between the two fields. From this perspective some authors of the period such as Christian Thomasius (1655-1728)-and later, as will be demonstrated, Johann Franz Budde (1667-1729)-developed a new way to study the history of philosophy.

From the 1660s, particularly after the foundation of the university in 1694, the city of Halle had been a location where opposition to Lutheran orthodoxy was growing. The presence of Thomasius and Budde (who moved to Jena in 1705), at the university and the Pietist community, in particular August Hermann Francke (16631727), in religious circles there, created an environment highly critical of the Lutheran tradition and promoted a new idea of religion and culture. The central point bonding men and perspectives often incompatible with one other was the need to rethink the Lutheran tradition, both from a theological and philosophical point of view. At the center of their reflection was the need to rethink Christianity and its relationship to pagan cultural tradition, through a careful study of the history of both the Church and philosophy. Studying the origins of philosophy and the various philosophical schools, also became a means to rethink the role of Lutheran theology and its relationship to the philosophical tradition, in particular the Aristotelian. In this new phase, the production of Lutheran universities, both within theological and philosophical faculties, focussed its attention precisely on these issues. The way the professors reflected on the various open questions took on different forms, literary genres and themes. In this debate the history of pagan philosophy and the role played by Jewish tradition in the transmission of human wisdom became the subjects for several works. Thomasius, for example, examined different philosophical methodologies, to find the best tool for challenging the dogmatism of Lutheran orthodoxy. By excluding sectarian, sceptical and syncretistic methodology he decided eclecticism was the best way to find an empirical method for his purposes.

According to Thomasius, the history of philosophy, gave scholars access to the different opinions of the philosophers of the past, stimulating the possibility to find the best solution to the problem of the present. ${ }^{24}$ Despite his refusal of scepti-

23 See Francesco Bottin and Mario Longo, "The History of Philosophy from Eclecticism to Pietism," in Models of the History of Philosophy, vol. 2: From the Cartesian Age to Brucker, eds. Gregorio Piaia and Giovanni Santiello (Dordrecht, Heidelberg, London and New York: Springer, 2011): 302-385. See also Valerio Marchetti, Saggi di storia della Chiesa evangelica tedesca. Tra XVII e XVIII secolo (Bologna: Cisec, 1999).

24 Christian Thomasius, Cautelae circa praecognita iurisprudentia (Halle: Officina Libraria rengeriana, 1710), 57-58: '1. Historia et philosophia sunt duo oculi sapientiae, quorum uno, qui caret, mon- 
cism in the interpretation of the history of philosophy, Thomasius was not insensitive to the contribution of scepticism to the struggle against dogmatism. He held history to be knowledge of the opinions of others, and thus more based on probability than certainty, and concluded thusly:

Even if, when studying philosophy, one is really further from sceptical doubt than from the infallibility of the dogmatics, yet where historical matters are concerned, especially in political questions, one should not believe even the half of what is said. But one does not doubt without a good reason for doubting. ${ }^{25}$

But scepticism, according to Thomasius, was not confined to the realm of history, in his work on Philosophia aulica, he maintained scepticism was not a philosophical school similar to that of the past; but was the main antagonist to dogmatism. ${ }^{26}$ The ambiguity of his statement mirrors the complexity of the debate in Germany toward scepticism. This Greek philosophy, in fact, was one of the topics on which several authors published short and long tractates, by defending or attacking his role within the history of pagan and Christian philosophy. ${ }^{27}$

Johann Franz Budde, student and then colleague of Thomasius, participated in the debate on the history of philosophy. Born in Anklam in 1667, he studied oriental languages, theology and philosophy at the University of Wittenberg. In 1693 he moved to Halle, where he met August Hermann Francke and Christian Thomasius.

oculus est ob summam utriusque connexionem [...] 9. Historia est de sensionibus alienis. Philosophia ratiocinatur de sensionibus propriis et alienis. 10. Utiles vero quam maxime sunt sensiones alienae ad studium sapientiae, quia partim adiuvant imperfectionem et insufficientiam propriam, partim quia multum prosunt ad emendationem.'

25 Ibidem, 68: 'Uti tamen in studio philosophico a dubio sceptico proprius abest, quam ab infallibilitate dogmaticorum, ita etiam circa historias, potissimum publicas, vix dimidiam partem credit. Interim tamen nunquam dubitat sine iuxta ratione dubitandi.' The English translation is in Mario Longo, "Christian Thomasius (1655-1728)," in Models of the History of Philosophy, vol. 2, 317.

26 Christian Thomasius, Introductio ad philosophiam aulicam (Halle: Officina Libraria rengeriana, 1702), 17-18: 'Pyrrhonii vero ne illud quidem comprehendi dicerent, quod aiebant, unde non tam sectam philosophorum constituerunt Sceptici, quam hostes communes omnis philosophiae, quae ab aliqua determinatione incipit (et propterea a philosophis dogmatica ad differentia sceptica dici solet) fuerunt.' On the use of scepticism in the debate on historical methodology, see Markus Völkel, 'Pyrrhonismus historicus" und "fides historica": die Entwicklung der deutschen historischen Methodologie unter dem Gesichtspunkt der historischen Skepsis (Frankfurt am Main: Lang, 1987).

27 I list just few works on this topic: Heinrich Askan Engelken, Johann E. Udam (risp.), Dissertatio de Scepticismi ortu et progressu (Rostock: Nicolas Schwiegerovius, 1702); Johann Christian Wolff, Programma de hodierno Scepticismo philosophico eiusdem causis (Wittenberg: Christian Gerdesil, 1710); Johann Brucker, "De Pyrrhone a scepticismi universalis macula absolvendo," in Miscellanea Lipsiensia ad incrementum rei litterariae edita, vol. 5 (Leipzig: Haeredes Lanckisianorum, 1716); Sextus Empiricus, Opera ... Graeca ex Mss. Codicibus castigavit, versiones emendavit supplevitque et toti operi notas addit J. Albertus Fabricius (Leipzig: Johann Friderick Gleditsch, 1718). The history of scepticism in Germany in the seventeenth and eighteenth century has not received sufficient attention in the field of studies. 
Budde was involved in the work of Thomasius and the Halle milieu in transforming Lutheran culture and published several tractates on different topics. Among the various works he wrote in this period, one is particular important for this analysis, the Introduction to Jewish Philosophy. ${ }^{28}$ The treatise was part of a wider project on the general history of philosophy, its origin and link to the history of Christianity. He had already discussed the topic in other works: Firstly, in two short essays published in a journal edited in Halle from 1700 to 1704, and then in a tractate on the philosophy of Spinoza. ${ }^{29}$ Budde developed a new idea of the history of human wisdom, by maintaining it to be possible to identify a common origin of the history of philosophy and theology. He discovers this in the first steps of the history of Hebrew wisdom, which Budde defines as philosophia mystica or theosophia, and then as Kabbalah. Budde's main task was to find a common origin of the two histories (philosophy and theology), for the purpose of reconsidering the relationship between Aristotelism and Lutheranism. By using the Jewish tradition, and inserting it in the wider history of ancient wisdom (prisca theologia) he was able to weaken the role played by Aristotlean philosophy and reinforce the effort of his group to reform Lutheran tradition. ${ }^{30}$

28 Johann F. Budde, Introductio ad Historiam Philosophiae Ebraeorum (Halle and Magdeburg: Orphanotrophius, 1702). On Budde's view of Jewish philosophy, see Wilhelm Schmidt-Biggemann, "Die Historisierung der 'Philosophia Hebraeorum' im frühen 18. Jahrhundert. Eine philosophisch-philologische Demontage," in Historicization-Historisierung, ed. Glenn W. Most (Göttingen: Vandenhoek \& Ruprecht, 2001): 104-128; idem, Geschichte der christlichen Kabbala, vol. 3 (Stuttgart: Bad Cannstatt, 2013), 243-270; Valerio Marchetti, "Il teologo Johann Franz Budde (1667-1729) e la filosofia ebraica," in L'interculturalità dell'ebraismo, ed. Mauro Perani (Ravenna: Longo, 2008): 299-314; Haim Mahlev, "Kabbalah as Philosophia Perennis?: The Image of Judaism in the German Early Enlightenment: Three Studies," Jewish Quarterly Review 104.2 (2014): 234-257. On the debate on Kabbalah and Jewish Philosophy, especially between Budde and Johann Georg Wachter, see Schmidt-Biggemann, Geschichte der christlichen Kabbala, vol. 3, 214-242.

29 Johann F. Budde, "Observatio I. Origines philosophiae Mysticae, sive Cabbalae Veterum Ebraeorum brevis delineatio," Observationum selectarum ad rem litterariam spectatium 1 (1700): 1-26; idem, "Defensio Cabbalae Ebraeorum contra auctores quosdam modernos," ibidem, 207-231; idem, Dissertatio philosophica de Spinozismo ante Spinozam [...] submittit Ioannes Fridericus Werder (Halle: Ch. Henckel, 1706). This last work, a dissertation discussed at the University of Halle, was a response to Johann Georg Wachter, Der Spinozismus im Jüdenthumb (Amsterdam: Wolters, 1699). The debate on Spinoza's philosophy was of course linked to the discussion on Jewish philosophy; see, e.g., David Bell, Spinoza in Germany from 1670 to Age of Goethe (London: Institute of Germanic Studies, University of London, 1984); Winfried Schröder, Spinoza in der deutschen Frühaufklärung (Würzburg: Könighausen \& Neuman, 1987).

30 The inclusion of Jewish tradition within the history of philosophy was also present in the work of a scholar close to the Pietist milieu, Johan Wilhelm Zierold (1669-1731); see Mario Longo, "Johan Wilhelm Zierold (1669-1731)," in Models of the History of Philosophy, vol. 2: 323-331. On the links between history of philosophy and Pietism, see Martin Gierl, Pietismus und Auklärung. Theologische Polemik und die Kommunikationsreform der Wissenschaft am Ende des 17. Jahrhunderts (Göttingen: Vandenhoeck \& Ruprecht, 1997); Jean-Marie Carré, "Le piétisme de Halle et la philosophie des Lumières (1690-1750),” Revue de synthèse historique 37.3, n. 81 (1913): 279-308. 
As has been observed, the first attempt to analyse Jewish philosophy was published in the journal Observationes selectae edited in Halle by Budde and Thomasius. All the works in this collection appeared anonymously and encapsulated the thought of the school of Halle. The school was based on the principles already mentioned: anti-Aristotelism, anti-dogmatism both in the cultural and religious domain, and a harsh criticism of Lutheran orthodoxy. ${ }^{31}$

\section{Jacob Reimmann and Jewish Scepticism}

In the eighth volume of this journal, another work on the history of Jewish philosophy was published. Its author was Jacob Friedrich Reimmann, and the essay bore the provocative title: "Was Salomon a Sceptic?".32

Reimmann was born in Gröningen near Halberstadt in 1668, and studied theology and philosophy for two years at the University of Jena. He then became director of the school of Halberstadt, and continued to work in the school system of his town. He was also involved in religious life: he became a deacon in 1714 and preacher at Halberstadt, and went on to become superintendent of the churches at Hildesheim. He died in the same town in 1743. Throughout his life, he remained in contact with the most eminent figures of the time, such as Thomasius and Gottfried Wilhelm Leibniz (1646-1716) and published several works on a variety of subjects both in Latin and in German. Influenced by Halle's milieu, he saw his main task to be combining rational thought and Lutheranism, which incurred going beyond traditional German scholasticism. ${ }^{33}$

He dealt with the Jewish tradition and its theology and philosophy in various works, both in Latin and German. He published a long and articulate treatise entitled Versuch einer Enleitung in die Historie der Theologie insgemein und Juedischen Theologie ins besondere (Attempt at an Introduction to the History of Theology in General

31 On the authorship of the different essays published in this collection, see Christoph August Heumann, "Revelatio auctorum Observationum Halensium Latinarum," Miscellanea Lipsensia Nova 1 (1742): 292-318. In addition to Budde's essays published in the first volume there is also Christian Thomasius, "Observatio II. Scholae quid? Et Quomodo ab Academiis differant?," Observationum selectarum 1 (1700): 26-35.

32 Jacob F. Reimmann, “An Salomon fuerit Scepticus," Observationum selectarum 8 (1704): 327-367. 33 On Reimmann, see Theodor Günther, Jacob Friedrich Reimmann (1668-1743). Mühsal und Frucht (Köln: Günther, 1974); Ralph Häfner, "Das Erkenntnisproblem in der Philologie," in Philologie und Erkenntnis. Beiträge zu Begriff und Problem frühneuzeitlicher Philologie, ed. Ralph Häfner (Tübingen: Max Niemeyer, 2001): 93-128; Martin Mulsow and Helmut Zedelmaier, eds., Skepsis, Providenz, Polyhistorie. Jakob Friedrich Reimmann (1668-1743) (Tübingen: Max Niemeyer Verlag, 1998); Winfried Schröder, "Einleitung," in Jacob F. Reimmann, Historia Universalis atheismi et atheorum falso et merito suspectorum, ed. Winfried Schröder (Stuttgart and Bad Cannstatt: Frommann-Holzboog, 1992): $7-37$. 
and Jewish Theology in Particular), published in Magdeburg in $1717 .{ }^{34}$ Reimmann dedicated an entire work to the study of atheism, a topic very much en vogue at the time, with a chapter specifically devoted to the atheism of the Jews, leading, inevitably, to a discussion of Jewish philosophy itself. ${ }^{35}$ But in other short tractates, such as the essay dedicated to the four elements, he always made reference to the Jewish tradition. ${ }^{36}$

Reimmann was, therefore, well aware of the importance of the discussion on Jewish tradition for the debate on the history of philosophy and for the history of theology, however, he developed his idea of Jewish philosophy through a completely different approch. He decided to combine this topic with another theme discussed in that period; scepticism and in so doing combined them in an original way. Reimmann chose the figure of Solomon primarily because traditionally, and especially in the book of Ecclesiastes, the Jewish king had expressed doubts about the ability of the human mind to know. Clearly Reimmann is to use his figure to support his model of philosophy, as will be demonstrated. It is interesting to note that from now on the figure of Solomon becomes important for the debate on scepticism in Germany. ${ }^{37}$

Reimmann divided his essay on Solomon into two parts. In the first he discusses the 'nature' of Jewish philosophy, and its link to sceptical tradition. In the second he defends his statement against the critique of his opponents, in particular from the accusations of Protestant theologian Joachim Lange (1670-1744).

From the very beginning, Reimmann criticised the uses several scholars had made of the Jewish philosophical tradition. He underlined three aspects in particular: 1) Many scholars, especially the historians of philosophy, have maintained that all the patriarchs, leaders and kings of the Jews have been philosophers (even in

34 Jacob F. Reimmann, Versuch einer Enleitung in die Historie der Theologie insgemein und Juedischen Theologie ins besondere (Magdeburg: Christoph Seidel, 1717). In this work, for example, he discussed the interpretation of Kabbalah in Budde's work; cf. ibidem, 333-459 on kabbalistic theology and 350 - 351 on Budde's interpretation. On Reimmann's interpretation of Kabbalah, see Mahlev, "Kabbalah as Philosophia Perennis?," 249-255.

35 Cf. Jacob F. Reimmann, Historia Universalis atheismi et atheorum falso et merito suspectorum (Hildesheim: L. Schröder, 1725), 24-50.

36 See, e. g., Jacob F. Reimmann, "Observatio III. Nescire Philosophos adhuc quid sit aer," in Observationum selectarum 5 (1700): 85: "Etenim ut ab Hebraeis quorum philosophia procul dubio est antiquissima faciamus initium, hi aeris naturam usque adeo ignorarunt, ut ne nomen quidem habuerit cognitum;' idem, “Observatio IV. Nescire Philosophos quid sit aqua, in Observationum selectarum,” ibidem, 109: 'Etenim si Hebraeorum Cryptas philosophicas, qua fas est diligentia perreptamus, de divisione quidem aquarum hinc atque hinc quaedam vestigia deprehendimus, sed de definitione earundem, ne gru quidem. Et ipsae quoque divisiones sic comparatae sunt, ut nobis ignorantiam nostram exprobrare videantur. Ut enim de divisione rabbinica et kabbalistica nil dicam in praesenti, qua aquas in masculas et foeminas disponere consueverunt.'

37 On Salomon and scepticism, see, e. g., Stuart Weeks, Ecclesiastes and Scepticism (New York: T \& T Clark International, 2012). 
the absence of any evidence). ${ }^{38}$ 2) The Hebrew patriarchs were often seen as dogmatic philosophers. ${ }^{39}$ 3) Their philosophy had been interpreted in different ways according to the thought of their interpreters. (e.g. Reimmann noted, Moses was seen at the same time as a Cartesian philosopher, an Aristotelian, and so on). ${ }^{40}$ The first critique was addressed to all the previous traditions that, as seen above, have used Jewish wisdom to legitimise differing philosophical ideas. He probably had Budde's work in mind too for, as already mentioned, Budde presented Judaism as the space where it would be possible to find the common origin of philosophy and theology.

Reimmann distances himself from previous tradition on the one hand, but on the other, he decided to follow the strategy of the historians of philosophy in using Jewish wisdom to legitimise his philosophical ideas. He maintains that after Job, King Solomon was the only Jewish man possible to be considered a true philosopher. ${ }^{41}$ Reimmann analyses Solomon's thought by using different sources, and outlines the

38 Reimmann, “An Salomon,” 328-329: 'Cum multi omnino sint qui magno conatu nihil agere, et, uti Latinorum habet proverbium, "Tellenas conduplicare tricas," soleant. Tum illi cumprimis ad hanc

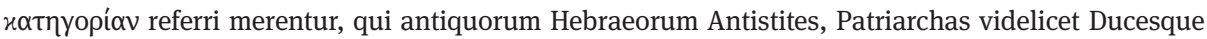
et Judices, imo etiam Reges, Pontifices aliosque etc. ad Philosophorum Dogmaticorum censum revocare eosque volentes nolentesque Magistros totius Encyclopaediae Philosophicae salutare consueverunt. Etenim ut non dicam, eos interdum ne per somnum quidem de iis scientiis ac disciplinis cogitasse, quas didicisse solicite, et posteros suos docuisse a nobis creduntur. Quam imbecillia ea sunt

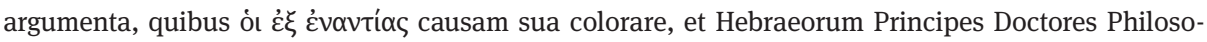
phiae creare annituntur?'

39 Ibidem, 330 - 331: 'Nam licet omnes, qui historiam Philosophicam contexuere adhuc, eosdem fecerint Dogmaticos, tamen recogitandum est, hoc factum esse a Dogmaticis, adeoque exinde non consequi revera fuisse tales. Siquidem hic mos est eorum qui partibus addicti sunt, ut describant homines, non ut fuerunt, sed ut fuisse cupiunt, fingantque sibi interdum et suo ingenio assentatores quosdam, quo sectam suam antiquiorem caeteris augustioremque efficiant.'

40 Ibidem, 331: 'Plane sicut experientia edocti sumus, Mosen jam Cartesianum, jam Aristotelicum, mox Atomisticum et Eclecticum factum esse, prout lectorem huic vel isti haeresi addictum indeptus fuerit.'

41 Ibidem, 332-333: 'Sed quid, ais, ille omnium Hebraeorum sapientum sapientissimus Rex Salomo istane $\alpha \dot{x} \alpha \tau \lambda \lambda \eta \psi \mid \alpha$ Sceptica, quam tu laudibus tantopere effers, excelluit? An putas enim fuisse Apor-

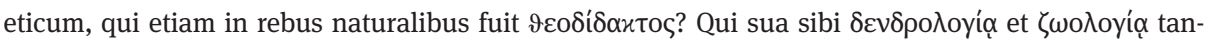
tam lucem circumfudit? Qui prosa juxta et versa oratione in toto orbe inclaruit, nihilque ignoravit eorum, quae ad dogmaticum eruditionis circulum requiruntur? Equidem fateor, haec non sine magno colore nobis objici posse a Dogmaticis; sed an pari soliditate objiciantur, adhuc animi vehementer pendeo. Nam primum nulla prorsus est consequentia, "Salomon in rebus naturalibus fuit $\vartheta \varepsilon о \delta i ́ \delta \alpha \varkappa t o \varsigma$, equidem fuit Dogmaticus." Siquidem et in rebus naturalibus potest esse $\vartheta \varepsilon о \delta i ́ \delta \alpha \varkappa t o \varsigma$ qui a Deo edoctus est, "nos in rebus naturalibus nil scire," adeoque nil affirmare certo de iis nec negare posse. Tum et Scepticus sibi $\delta \varepsilon v \delta \rho o \lambda$ oyía et $\zeta \omega$ o $\lambda$ oyía potest famam acquirere, si ostendat; Dogmaticos in his scientiae naturalis partibus eneptivisse adhuc, et nil nisi fumos suis discipulis vendidisse. Ac tandem in prosa juxta et versa oratione potest Scepticus inclarescere, nosseque omnia quae in Scholis Dogmaticorum proponuntur, non quidem ut pro veris certisque ea habeat, sed ut falsitatem et incertitudinem penitius cognoscat, eamque suis adversariis ostendat.' 
king's philosophy as anti-dogmatic thought linked to the sceptical tradition..$^{42} \mathrm{He}$ describes three qualities of Solomon's philosophy, and compares it with the philosophy of his own time. According to him, Solomon's thought had its origin in divine revelation, and not in natural illumination. ${ }^{43}$ Its object was the distinction between good and bad, and not, like the philosophy of Reimmann's time, between true and false, ${ }^{44}$ and it was a practical philosophy and not a theoretical one. ${ }^{45}$ He seems to adopt a traditional (conservative) attitude toward the new rationalistic philosophy of his day, by comparing, for example, divine and natural efficient cause. ${ }^{46}$ Indeed, throughout the history of its discovery during the early modern age, scepticism was often used as a tool against pagan philosophy, for example, in the work of Giovanfrancesco Pico della Mirandola. ${ }^{47}$

Reimmann, however, had a different plan in mind. When he describes the nature of Solomon's wisdom he underlines that the Jewish king was taught by God himself. ${ }^{48}$ This statement, he maintains, could be seen as evidence of the dogmatic nature of his thought, while it is the opposite. Reimmann writes:

First of all there is absolutely no consequentiality here: 'Solomon was taught by God in natural causes, therefore he was a dogmatic.' For even with regard to natural causes it can happen that the person who has been taught by God has been instructed by God that we know nothing about natural causes, or even that nothing certain can be affirmed or denied about them. ${ }^{49}$

42 Ibidem, 334: 'Plane sicur Rex sapientissimus Salomo c. I v. 17 scribit, se adjecisse animum non solum ad cognoscendam (Scepticorum) sapientiam (לדעת חכמה) sed etiam ad perspiciendam omnem (Dogmaticorum) insaniam et stoliditatem לדעת הללת ושכלות Conf. cap. VII v. 26.'

43 Ibidem, 334-335: 'Postea vero suspiriis devotis a Deo indeptum quidem sapientiam et Philosophiam, sed toto coelo a nostra, qua mundus hodie decipitur, diversam. Etenim quod ad ejus causam efficientem attinet, non a lumine naturae, nec ab institutione, nec ab exercitatione eadem manaverat,

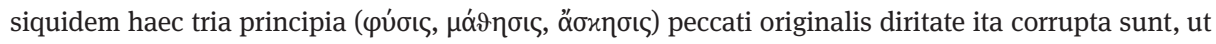
non nisi eruditio superficiaria et falsa ab iis exspectari possit, sed a lumine supernaturali et divino duxerat originem.'

44 Ibidem, 336: 'Quamobrem mirandum etiam non est, quod nostra Philosophia a Solomonaea objecto etiam differat. Cum enim illa in veritate et falsitate rerum eruenda occupetur cumprimis, haec in bonitate et malitia detegenda solummodo districta est, ut patet ex 1 Reg. III v. 9 ubi petit siti Salomo sapientiam non quidem ad discernendum verum a falso, sed tantum bonum a malo.'

45 Ibidem, 337: 'Porro quod ad formam Philosophiae Salomonaeae est, consistit illa tantum in praxi, i.e. ut Proverb. IX v. 6 dicitur, "in omittendis stultorum vitiis et perpetrandis prudentum virtutibus," quo nomine non parum a nostra philosophandi ratione distat. Nam licet nos in disciplinis practicis eundem cum eo finem habere videri discupiamus; revera tamen longe ab eo absumus, quia nostrae disciplinae non re, sed nomine tantum sunt practicae, dum a principio ad finem usque otiosis speculationibus de virtutum definitionibus, divisionibus, axiomatis, etc. refertae sunt et constipatae.'

46 See note 39.

47 On fideistic scepticism, see, e.g., Richard Popkin, The History of Scepticism: From Savonarola to Bayle (Oxford: Oxford University Press, 2003): 20-24.

48 Reimmann uses the Greek word $9 \varepsilon 0 \delta i ́ \delta \alpha \varkappa \tau o \zeta$.

49 Reimmann, "An Salomon," 333: 'Nam primum nulla prorsus est consequentia, "Salomon in rebus naturalibus fuit $\vartheta \varepsilon \sigma \delta i \delta \alpha \varkappa \tau o \varsigma$, equidem, fuit Dogmaticus.” Siquidem et in rebus naturalibus potest 
Thus, he seems to strengthen the definition of fideistic scepticism, but, on the other hand he goes further and presents this divine scepticism as the only useful critical tool of dogmatic thought in the philosophical debate of his time. In the confrontation between the old philosophy of Salomon and the thought of his time, a new philosophy emerges using Aristotelian categories, but entirely different to the scholastic thought in the Lutheran Universities. Reimmann discusses Aristotle's definition of the intellect and his distinction between theoretical and practical intellect. Aristotle himself and his commentators considered theoretical intellect to be superior to the practical, but Reimmann overturns this hierarchy: he uses scepticism to attack Aristotelian theoretical intellect, and exalt the practical. ${ }^{50}$ He shows that Jewish tradition could be used in a completely different way. In his view, Jewish philosophy was not a tool to legitimise a philosophical system, but a strategy or instrument to criticise the other dogmatic philosophies.

In the second part of his tractate, Reimmann defends his interpretation from the critique of theologian Jacob Lange. It has been recorded that Reimmann told Lange of his interpretation of Solomon's philosophy during a private conversation in 1704, and the latter went on to attack him in his book Medicina mentis, published the same year in Berlin. ${ }^{51}$ Lange was one of the most important Pietist theologians of the time, he grew up in the Halle milieu, together with Francke and Thomasius, and then lived in Berlin contemporary to Spener..$^{52}$ Lange's tractate attempted to rethink the history of philosophy in the light of the Pietistic critique of the traditional orthodox Lutheranism. Thus, Reimmann's idea that the holy philosophy of Solomon corresponded to scepticism was unacceptable and, for Lange, clear evidence of atheism. ${ }^{53}$ Reimmann,

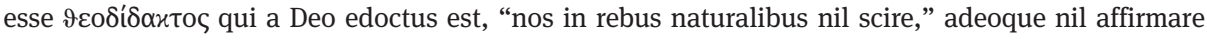
certo de iis nec negare posse.'

50 On this topic, as well as the Jewish philosophical debate in the Middle Ages, see Shlomo Pines, "Truth and Falsehood versus Good and Evil: A Study in Jewish and Genral Philosophy in Connection with the Guide of the Perplexed I, 2," in Studies in Maimonides, ed. Isadore Twersky (Cambridge, MA: Harvard University Press, 1990): 95-127. I am grateful to Daniel Davis for drawing my attention to this article.

51 Joachim Lange, Medicina mentis, qua praepostera philosophandi methodo ostensa ac reiecta, secundum sanioris philosophiae principia, aegrae mentis sanatio ac sanatae usus in veri rectique investigatione ac communicatione (Berlin: Wessel, 1704). On the debate between Reimmann and Lange, see Martin Mulsow, "Die Paradoxien der Vernunft. Rekonstruktion einer verleugneten Phase in Reimmanns Denken," in Skepsis, Providenz, Polyhistorie. Jakob Friedrich Reimmann (1668-1743), eds. Martin Mulsow and Helmut Zedelmaier, 26 -32. Cf. Reimmann, "An Salomon,” 344: 'Et quia Auctori huic, quem alias ob pietatem et eruditionem magni facio, paneque ita rationem duco, eum non malo animo hunc paragraphum Historiae suae inseruisse; Ita collubuit hanc nostram sententiam, quam eidem privatim communicaveramus, publicere rejicere, eamque ceu impiam et praeposteram condemnare, fas erit, opinor, ad haec ejus dubia jam publice respondisse.'

52 On Lange's biography, see Jendris Alwast, “Lange, Joachim,” Neue Deutsche Biographie 13 (1982): 548f. [Online-Version]; URL: https://www.deutsche-biographie.de/pnd118569376.html\#ndbcontent.

53 Lange, Medicina Mentis, 393: 'Videtur laudatae sapientiae Salomonaeae hominisque sapientis officio obstare quae ejus tradit Ecclesiastes? Ita quidem judicant, qui citra Salomonaeum principium, 
thus, spends the last part of his tractate defending not only his interpretation of Solomon's philosophy, but largely scepticism itself. At the end of his work he openly quotes Sextus Empiricus to make clear to his adversaries scepticism was not a philosophy which 'did not doubt all beliefs generally,' rather it 'doubted only uncertain or dubious things, which were investigated and disputed by the sciences of the dogmatics. ${ }^{54}$ Finally, he concludes that scepticism was not addressed to theological wisdom:

[...] so, far be it from me to place all of Solomon's doctrine within the framework of akatalepsia; rather, I will distinguish as carefully as possible theological questions from philosophical ones, theory from praxis, dogmas about the existence of things from dogmas about the essence of things. ${ }^{55}$

Surely Reimmann was influenced by Halle's Enlightment. But his idea of scepticism cannot be traced exclusively to the 'rationalistic' use of scepticism at the time. The sources he uses refer, on the one hand, to the French tradition: two long quotations taken from the philosopher François de La Mothe Le Vayer (1588-1672). ${ }^{56}$ While on the other, mystic and anti-Cartesian Pierre Poiret (1646-1719) is mentioned at the end of the treatise. ${ }^{57}$ The reference to his work, which had been re-edited only a

quod ille in timore Dei collocat, e Salomone impie et praepostere philosophantur. Ex horum numero sunt, qui ad hujus libri ductum non dubitant, e Salomone alterum quasi Pyrrhonem seu Scepticum facere ejusque doctrinam $\dot{\varepsilon} v \alpha \dot{x} x \alpha \alpha \lambda \eta \psi(\alpha$ seu ignorantia et fluctuatione Sceptica ponere. Qui ubi principium suum: "Nos scire nihil," in hoc libro inveniant, et quid e nihilo suo derivari velint, equidem non deprehendo. Si quis vero principia et indolem Philosophiae Salomonaeae ex hoc praecipue libro eruere voluerint, inter alia secreta meditatione excutiat sequentia loca, in quibus simul caeterorum clavis est c. 1 v. 2; c. VII v. 13, 20, 30; VIII 12, 13; IX v. 18; XI v. 9, 10; XII v. 7, 13, 14.'

54 Reimann, “An Salomon,” 361-362: 'Etenim ut ipsi olim Sceptici non generatim de omnibus dubitabant dogmatis et v. g. calefacti vel frigefacti non dicebant, puto me non calefieri vel frigefieri; sed, ut expresse habet Sextus Empiricus 1. 1 hypothes. Pyrrhon. c. VII p. m. 12 de iis tantum, quae erant de rebus incertis ac dubiis, de quibus in Dogmaticorum scientiis quaeritur, et ambigitur.'

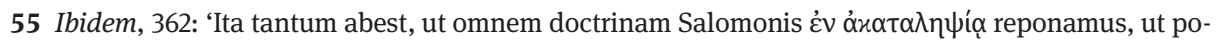
tius Theologica a Philosophicis, theoretica a practicis, et dogmata de rerum existentia a dogmatis de rerum essentia, quam solicitissime distinguamus.'

56 See Reimmann, "An Salomon," 348-350 and 353-360. Both are quotations from François La Mothe Le Vayer, De la Vertu des Payens, in idem, Oevres (Paris: Augustin Courbe, 1662): 662. On La Mothe Le Vayer, see René Pintard, Le Libertinage érudit dans la première moitié du XVIIe siècle (Geneve: Slatkine, 1983), 505-538; Popkin, The History of Skepticism, 82-87. As Martin Mulsow has pointed out, the history of Pyrrhonism and of scepticism in general has opened the door to the reception of the Libertinage érudite in Germany during the first Enlightenment; see Mulsow, "Die Paradoxien der Vernunft. Rekonstruktion einer verleugneten Phase in Reimmanns Denken,” 32; idem, “Appunti sulla fortuna di Gabriel Naudé nella Germania del primo illuminismo,” Studi filosofici 14/15 (1991-1992): $145-156$.

57 See Reimmann, “An Salomon,” 366: 'Unicum tantummodo locum de commodis Philosophiae scepticae adjiciam, quem habet $\mathrm{Cl}$. Auctoris nostri dux et Coryphaeus Petrus Poiretus in praefat. Tom. 1 de Oeconomia divina Edit. Amestelod. in 12mo 1687. Ubi ita infit: "Cette sentence peut assi servir aux bonnes ames pour les porter à l'admiration des grandeurs adorables de Dieu à la recherche 
few years earlier by Thomasius, shows us the complexity of the sources of his thought, which certainly require further inverstigation..$^{58}$

\section{Conclusion}

Reimmann's involvement in Thomasius and Budde's Observationes selectae project shows that he agreed with the attempt the Halle school made to attack dogmatism, and re-think Lutheran orthodoxy. However, he believed that Thomasius and Budde's tools, and particularly eclectic philosophy, were insufficient. ${ }^{59}$

Reimmann argues that Solomon was the best example of the Jewish philosophical tradition, and as the Jewish king lived centuries before Pyrrhon, it would be fair to claim him as the real founder of scepticism. ${ }^{60}$ The relationship between scepticism and the Jewish tradition, for Reimmann, served to strengthen the main characteristic of that kind of Greek philosophy-that being its acknowledgement of human ignorance and doubt. Reimmann, however, uses fideistic garb to legitimise the sceptic strategy against dogmatism and traditional knowledge.

In so doing, he transforms the idea of Jewish philosophy in the eyes of Christians. As we have seen, from the beginning of the early modern age, Christian culture used the Jewish tradition for the purpose of legitimising particular philosophical systems-e.g. Platonism, Atomism, or Cartesian thought-and also to give them a holy veneer. This scheme established a strong relationship between the Jewish tradition and pagan philosophy: it regarded the former as possessing a philosophical system and attributed an aura of holiness to the latter.

Reimmann went further in establishing a connection between the pagan tradition and the Jewish one, but he refused to attribute a given philosophical system to Jewish philosophy. According to him, thanks to their unique relationship with

de son amour, et en meme tems mettre à fond leurs coeurs en repos sur une infinité de difficultes dont on se tourmente l'Esprit sur autres choses."' Cf. Pierre Poiret, L'Oeconomie Divin ou Systeme Universel et Demontré des Oeuvres et des Desseins de Dieu envers les Hommes (Amsterdam: Henry Wetstein, 1687). On Poiret, see Marjolaine Chevallier, Pierre Poiret (1646-1719). Du protestatisme à la mystique (Geneve: Labor et Fides, 1994).

58 See Pierre Poiret, De eruditione triplici, solida superficiaria et falsa libri tres [...] accedit Christiani Thomasii nova praefatio (Frankfurt and Leipzig: Johann Friedrich Zeitler, 1708).

59 Martin Mulsow, "Eclecticism or Skepticism? A Problem of the Early Enlightenment," Journal of the History of Ideas 58.3 (1997): 468. See this article also for the influence that the work of Georg Struve had on Reimmann's thought; cf. Burcard Gotthelff Struve, Johann Christoph Dorn (resp.), Dissertatio de doctis impostoribus (Jena: Litteris Mullerianis, 1703).

60 Reimmann, “An Salomon,” 361: “Tertio nec illud bene dicitur, quod ait, hos homines e Salomone alterum quasi Pyrrhonem vel Scepticum facere. Qui enim illi alterum e Salomone possent facere Pyrrhonem, cum alter ratione ordinis priori sit posterior, et Salomon Pyrrhonem fere octingentos annos

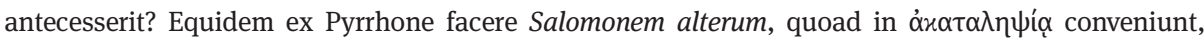

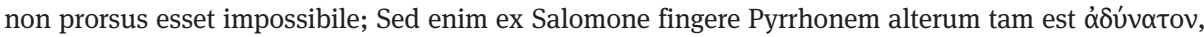
quam ipsum archetypum ex ectypo exprimere.' 
God, the Jewish philosophers (Job and Solomon), were the only ones aware of the weakness of the human mind. The German scholar, therefore, used the Jewish tradition to legitimise not so much a philosophical system, as a philosophical strategy that was to undermine traditional knowledge. Jewish philosophy, for Reimmann's intentions, had to lose its legitimising role and transform itself into its opposite, that is to say, into an instrument for criticising all dogmatic philosophical systems.

Reimmann's idea of Jewish philosophy was not developed any further, nor did it influence subsequent reflections on the topic. On the contrary, it provoked several opposing reactions. Largely he was accused of wanting to transform Solomon into an atheist. ${ }^{61}$ Despite this, however, the recognition of Jewish philosophy as a sceptical philosophy, and the justification of sceptical doubt as the only tool for philosophical knowledge, was bound to have significant consequences, not only for the history of Jewish philosophy in the Lutheran world, but above all, for the history of philosophy in general.

After Reimmann, Jewish philosophy began to be seen in a different way by Christian eyes: it became less important as a means to defend specific philosophical systems, or to understand the relationship between philosophy and theology. It was 'normalised' and became equal to all other non-Greek philosophical traditions. Reimmann's work may not have played a role in this process, but it almost certainly stands as evidence of this transformation.

61 Reinhard H. Roll, Salomo Scepticismi crimine contra iniustam observatoris Halensis imputationem (Rostock: Impensis Wepplingianis, 1710); Johann Cristoph Ortlob, Georg Stisser (resp.), Dissertatio processum Salomonis contra Simei (Leipzig: Literis Immanuelis Titii, 1719). 
